\title{
ДОСЛІДЖЕННЯ ДИСФУНКЦІЇ МІОКАРДА У ВІЙСЬКОВИХ ІЗ БОЙОВОЮ ТРАВМОЮ
}

\author{
С. В. Софрієнко, І. А. Чайковський \\ Національний військово-медичний клінічний центр «ГВКГ» України \\ ${ }^{1}$ /нститут кібернетики імені В. М. Глушкова НАН України
}

\section{RESEARCH DYSFUNCTION OF THE MYOCARDIUM FOR THE MILITARYMEN WITH COMBAT TRAUMA}

\author{
S. V. Sofiyenko, I. A. Chaykoskyi ${ }^{1}$ \\ National Military Medical Clinical Centre of Ukraine, \\ ${ }^{1} \mathrm{~V}$. M. Hlushkov Institute of Cybernetics of NAS of Ukraine
}

Вступ. Первинний аналіз результатів сучасної бойової травми свідчить про переважання у постраждалих травми мінно-вибухового генезу зі значним обсягом ураження тканин організму та розвитком супутнього ураження внутрішніх органів.

При травматичній хворобі, що виникла внаслідок політравми тяжкого ступеня, пошкодження внутрішніх органів виявляється у 92,8 \% потерпілих.

При травматичній хворобі, що супроводжувала мінно-вибухову травму, швидко розвиваються гіпоксемія, ендотоксемія, які супроводжуються тяжкими та небезпечними для життя порушеннями зі сторони серцево-судинної системи. Від 6,4 \% до 59,6 \% випадків механічних травм різної локалізації характеризувались розвитком вторинних змін серця у вигляді посттравматичної міокардіодистрофії.

Мета дослідження: оптимізація діагностики гемодинамічних порушень та дисфункції вегетативної нервової системи у військовослужбовців, які брали участь у проведенні антитерористичної операції (АТО) та отримали травматичні ушкодження різного ступеня тяжкості.

Результати та їх обговорення. В основу роботи було покладено результати клініко-інструментального обстеження 28 військовослужбовців, які брали участь у проведенні АТО на Сході України та перебували на стаціонарному лікуванні в хірургічних відділеннях госпіталю (віком у середньому $(33 \pm 8)$ років).

При проведенні дослідження через 2 тижні після госпіталізації ми відмітили покращення показників систолічної функції ЛШ. При цьому відмічали зменшення кінцевосистолічного індексу при незміненому кінцеводіастолічному (22,8 $\pm 7,8$ проти $20,6 \pm 6,4$, () С. В. Софієнко, I. А. Чайковський $\mathrm{p}<0,05)$, внаслідок чого відповідно збільшились фракція викиду ЛШ (з 61,7 $\pm 6,2$ до $65,4 \pm 6,7, \mathrm{p}<0,05)$, хвилинний об'єм кровообігу і серцевий індекс. Водночас також незначно покращилась діастолічна функція ЛШ. На це вказує збільшення співвідношення Е/А трансмітрального кровотоку $(1,39 \pm 0,36$ проти $1,83 \pm 0,36, p<0,05)$ за рахунок зменшення вкладу систоли передсердя. Виявлені зміни можуть свідчити про те, що в ранній період травматичної хвороби виникає систоло-діастолічна дисфункція міокарда.

При аналізі даних ВСР відмічено достовірне збільшення середніх значень SDNN, i SDANNн порівняно 3 контрольною групою - відповідно $(61 \pm 55)$

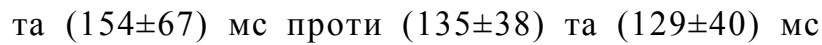
$(\mathrm{p}<0,05)$. Аналогічно у групах змінювалися показники SDANNд і $\mathrm{SDANH}$ - $(155 \pm 54)$ та $(124 \pm 48)$ мс проти $(124 \pm 36)$ та $(97 \pm 33)$ мс відповідно.

Висновки. 1. Попередньо отримані нами дані свідчать, що патологія серцево-судинної системи у постраждалих в зоні проведення АТО виходить на перше місце, а її ознаки також з'являються вже в перші 10 діб після нанесення бойової травми.

2. Доведено, що у військовослужбовців із післятравматичним стресовим розладом, які брали участь у АТО, показники ВСР були вірогідно меншими, порівняно із іншими військовослужбовцями, що свідчить про те, що отриманий стрес негативно впливає на стан як симпатичної, так і парасимпатичної ділянок ВНС.

3. Патологічні показники ВСР у військовослужбовців-учасників АТО із післятравматичним стресовим розладом слід вважати предиктором розвитку серцево-судинних захворювань у майбутньому. 